Wahana Akademika

Vol. 2 No. 2, Oktober 2015

\title{
FIQH SOSIAL KIAI SAHAL SEBAGAI FIQH PERADABAN
}

\section{Jamal Ma'mur Asmani'}

\section{A. Pendahuluan}

Kiai Sahal boleh meninggalkan kita, tapi hanya jasadnya, pemikirannya tidak pernah mati. Seperti dalam sebuah syair, bahwa jasad orang alim belum dikubur, tapi gagasan dan pemikirannya akan senantiasa hidup sepanjang masa, dikaji oleh generasi sesudahnya. Jika kebesaran Imam Syafi'i ditopang oleh generasi sesudahnya, seperti Imam Muzani dan Imam Buwaithi, maka kebesaran Kiai Sahal sangat tergantung kepada generasi sesudahnya, mau dan mampukah mengkaji pemikiran besar Kiai Sahal sebagai salah satu alternatif pemikiran besar di era global sekarang ini. Tulisan ini ingin mengkaji pemikiran Kiai Sahal yang sudah dikenal luas oleh publik, yaitu fiqh sosial.

Di tengah berjibunnya ide-ide pemikiran progresif dari dalam dan luar negeri yang ratarata mengidolakan liberalisme, sebagaimana digaungkan Nasr Hamid Abu Zaid, Moh. Arkoun, Mahmud Mohammad Thoha, Hasan Hanafi, Abid Al-Jabiri, Abdullah An-Naim, Moh. Syahrur, Fazlur Rahman, Asghar Ali Enggener, Aminah Wadud, Munawir Syadzali, Nur Cholis Madjid, A. Syafi'i Ma'arif, Jalaluddin Rahmat, Kuntowijoyo, Abdurrahman Wahid, Masdar Farid Mas'udi, Amien Rais, Komaruddin Hidayat, Ulil Abshar Abdalla, Abdul Muqsith Ghozali, Luthfi AsSyaukani, Guntur Romli, Husain Muhammad dan lain-lain, eksistensi dan kontribusi khazanah klasik yang terkenal dengan 'kitab kuning' dipertanyakan banyak pihak. Ia seperti terkena krisis identitas, krisis orientasi, dan krisis eksistensi. Ia identik dengan konservatisme, tradisionalisme, dan fanatisme. Bahkan ia dituduh sebagai sumber munculnya radikalisme dan fundamentalisme pemikiran dan gerakan keagamaan. Lebih tragis dan ironis lagi, kalangan Barat menganggapnya biang teorisme.

Munculnya fiqh sosial yang digagas oleh KH. MA. Sahal Mahfudh Mahfudh, eksponen pesantren dan NU, ibarat cahaya ditengah kegelapan yang memancarkan aura dan spirit optimisme, konfidensi, dan revitalisasi khazanah klasik. Fiqh sosial selain mendalami makna teks-teks keagamaan (al-nushus al-diniyah), juga mengikuti perkembangan realitas kekinian, bahkan memandu, merubah dan mendorongnya secara sistematis dan kontinu agar sesuai dengan spirit agama yang dipancarkan fiqh yang berintikan kemaslahatan, kesejahteraan, keadilan, dan kemakmuran.

Dalam konteks ini, fiqh sosial adalah fiqh kebudayaan, artinya fiqh yang mengobarkan

1 Penulis buku Fiqh Sosial Kiai Sahal Mahfudh, Antara Konsep dan Implementasi, Peneliti Fiqh Sosial Institute Staimafa Pati, Mahasiswa S3 Islamic Studies IAIN Walisongo Semarang, 085726836184. BNI Cabang Pati 0159858616 atas nama Jamal Ma’mur, HP. 085726836184 
semangat transformasi, tidak hanya teori. KH. MA. Sahal Mahfudh terkenal dengan fiqh sosialnya, tidak hanya sekadar ide, konsep, paradigma, dan teori, tapi juga bukti konkret. Ia mempunyai karya sosial, tidak hanya karya intelektual. Ia melakukan pemberdayaan ekonomi kerakyatan dengan paradigma fiqh sosial. Ia menjadikan fiqh sebagai pijakan legitimasi dan aksi dalam kerja-kerja pemberdayaan. Ia gabungkan kemampuan berorganisasi, networking relationship, management, kepemimpinan dan charisma untuk menggelindingkan gagasan fiqh sosial di tengah realitas obyektif yang mengitarinya.

Dalam pembumian kerja pemberdayaan ini, KH. MA. Sahal Mahfudh menemukan kendala, yakni paradigma mayoritas para kiai Kajen yang menggunakan fiqh sebagai kacamata dalam merespons setiap masalah. Fiqh mereka adalah fiqh tekstualis, final, dan eternal. Para Kiai menuduh KH. MA. Sahal Mahfudh sebagai agent zionis dengan program pemberdayaan ekonomi kerakyatannya. Dalam konteks inilah, KH. MA. Sahal Mahfudh mengerahkan semua kemampuan terbaiknya untuk membuktikan bahwa fiqh tidak anti program pemberdayaan ekonomi kerakyatan, justru fiqh harus tampil sebagai pioneer kebangkitan ekonomi kerakyatan sebagaimana perintah Al-Qur'an dan Hadis Nabi.

Bagi KH. MA. Sahal Mahfudh, Fiqh bukanlah konsep dogmatif-normatif, tapi konsep aktifprogresif. Fiqh harus bersenyawa langsung dengan 'af'al al-mukallifin' sikap perilaku, kondisi, dan sepak terjang orang-orang muslim dalam semua aspek kehidupan, baik ibadah maupun mu'amalah (interaksi sosial ekonomi). KH. MA. Sahal Mahfudh tidak menerima kalau Fiqh dihina sebagai ilmu yang stagnan, sumber kejumudan dan kemunduran umat, Fiqh justru ilmu yang langsung bersentuhan dengan kehidupan riil umat, oleh sebab itu Fiqh harus didinamisir dan revitalisir agar konsepnya mampu mendorong dan mengarahkan umat Islam meningkatkan aspek ekonominya demi mencapai kebahagiaan dunia dan akhirat.

Kontekstualisasi dan aktualisasi Fiqh adalah dua term yang selalu dikampanyekan $\mathrm{KH}$. MA. Sahal Mahfudh baik secara 'qouli' (teks) melalui acara seminar, symposium, dan sejenisnya, 'kitabi' (tulisan) di Koran, majalah, makalah, dan sejenisnya, dan fi'li (tindakan) dalam bentuk aksi langsung ditengah masyarakat dengan program-program riil dan konkret yang menyentuh kebutuhan dasar masyararakat. Masyarakat tidak hanya diberi modal, tapi juga kemampuan dan pengawasan, agar mampu melakukan terobosan efektif dalam merubah kondisi miskin serba kekurangan menjadi serba cukup dan sejahtera.

Fiqh sosial KH. MA. Sahal Mahfudh dalam konseptualnya selalu mengacu pada lima prinsip pokok : Pertama, interpretasi teks-teks Fiqh secara kontekstual. Kedua, perubahan pola bermadzhab dari qouly (tekstual) ke manhaji (metodologis). Ketiga, verifikasi mendasar mana ajaran yang pokok (ushul) dan yang cabang (rufu'). Keempat, Fiqh dihadirkan sebagai etika sosial, bukan hukum positif negara. Kelima, pengenalan metodologi pemikiran filosofis, terutama dalam masalah sosial dan budaya. Fiqh sosial Kiai Sahal adalah model pengembangan fiqh NU yang kurang berkembang secara dinamis. Fiqh sosial adalah fiqh yang berorientasi 
maslahah dengan manhaj yang jelas. Inilah fiqh yang sudah dicita-citakan NU sejak Munas Lampung 19912. Bangunan fiqh ini menjadi embrio lahirnya fiqh peradaban.

\section{B. Potret Fiqh NU}

Fiqh adalah pengejawantahan praktis ajaran Islam dalam kehidupan sehari-hari. Sebagai santri atau anggota NU, mengambil hukum secara langsung dari al-Qur'an dan Hadits adalah tabu dan gege mongso. Itu sama dengan mujtahid mutlak yang menurut para ulama sudah tidak ada pada abad ke-5 Hijriyah, setelah banyaknya ulama mujtahid yang meninggal dan pengikut-pengikutnya sudah merasa cukup dengan hasil ijtihad guru-gurunya. Maka, saat itulah, memasuki abad ke-6, imam mujtahid terpersonifikasi dalam empat madzhab, Hanafi, Maliki, Syafi'i, dan Hambali. Empat madzhab ini dipilih karena kitab-kitab sudah terkodifikasi secara lengkap, para murid-muridnya aktif-dinamis-produktif dalam menyeleksi, mengkoreksi, dan mengembangkan pendapat imam-imamnya. Sedangkan imam madzhab yang lain, seperti Imam Sufyan al-Tsauri, Sufyan bin Uyainah, Laits bin Sa'd, Ishaq bin Rahawaih, Ibnu Jarir, Dawud, dan Auza'i, madzhabnya tidak dipilih karena pengikut-pengikut tidak aktif-dinamis-produktif dalam mengkodifikasi, mengkoreksi, dan mengembangkan pendapat-pendapat guru-gurunya. Sehingga dimungkinkan sulit mencari mata rantai (asanid) yang menghubungkan dengan guru yang bisa mengantisipasi perubahan (taghyir) dan pergantian (tabdil). ${ }^{2}$

Lembaga yang mempunyai legitimasi kuat dalam menetapkan hukum Islam adalah syuriyah melalui forum bahtsul masa'il, baik tingkat ranting, kecamatan, kabupaten, wilayah, dan muktamar. Bahtsul masail ini menampung masalah yang terjadi ditengah masyarakat (waqi'iyyah), kemudian dibahas status hukumnya melalui ibarat kitab kuning, lalu ditetapkan sebuah hukum setelah proses perdebatan seru, panjang dan melelahkan. Kalau belum ditemukan jawabannya maka dimauqufkan dan dilanjutkan pada pertemuan yang akan datang.

Menurut KH. MA. Sahal Mahfudh, Rais Am Syuriyah PBNU, kajian masalah hukum di NU masih belum memuaskan, untuk keperluan ilmiah maupun sebagai upaya praktis menghadapi tantangan-tantangan zaman. Salah satu sebabnya yang pokok adalah ketrikatan hanya terhadap satu madzhab (Syafi'i). padahal AD/ART NU sendiri menegaskan, bahwa NU menaruh penghargaan yang sama terhadap empat madzhab yang ada. Ketidakpuasan juga muncul akibat cara berpikir tekstual, yaitu dengan menolak realitas yang tidak sesuai dengan rumusan kitab kuning, tanpa memberikan jalan keluar yang sesuai dengan tuntunan kitab itu sendiri. Oleh sebab itu, menurut KH. MA. Sahal Mahfudh, komisi bahtsul masa'il NU masih memerlukan upaya peningkatan yang serius. Paling tidak supaya apa yang dilakukannya dapat mencapai tingkat ijtihad, meskipun hanya muqayyad sifatnya, tapi tidak sekedar mentathbiq (mencocokkan) kasus yang terjadi dengan referensi (maroji') tertentu saja. ${ }^{3}$

Ironisnya, mayoritas masyarakat sekarang ini, lanjut KH. MA. Sahal Mahfudh, sudah meninggalkan fiqh secara keseluruhan, atau tidak memahami keutuhannya. Yang pertama kali dan sangat mendesak dilakukan dalam kerangka itu adalah merubah wawasan masyarakat

2 Sayyid Alawi ibni Sayyid Ahmad al-Saqqof, Tarsyihul Mustafidin, Darul Fikri, hlm. 3

3 KH. MA. Sahal Mahfudh, Nuansa Fiqh Sosial, LkiS dan Pustaka Pelajar, 1994, hlm. 45-46 
tentang fiqh secara utuh dan menyeluruh, bukan saja terhadap masyarakat awam, tetapi terhadap kelompok yang merasa telah mampu memahami fiqh secara benar. Kekurangan kelompok terakhir ini adalah memposisikan Fiqh sekedar sebagai kodifikasi atau komplikasi hukum Islam. Dalam pandangan kelompok ini, fiqh adalah kompilasi hukum Islam yang sepenuhnya baku, karena itu terjatuh dalam asumsi bahwa Fiqh sama kuat dan sakralnya dengan al-Qur'an atau al-Hadits. Suatu pandangan yang bukan saja tidak proporsional bagi Fiqh itu sendiri, tetapi bahkan menurunkan derajat kalam Allah dan sunnah Rasul sebagai sumber hukum sepenuhnya universal. ${ }^{4}$

Sebagai contoh, disampaikan disini hasil bahtsul masail yang pernah penulis ikuti :

Pertama, ketika masih nyantri di Jombang, kebetulan dalam rangka haul KH. Bisyri Syansuri ada bahtsul masail se-Jawa Timur di Pondok Pesantren Mamba’ul Ma'arif Denanyar Jombang, ada keputusan yang ditelurkan, yaitu zakat tidak boleh dengan uang, tapi harus dengan barangnya (ain). Walaupun ada pendapat yang disampaikan Imam Ramli yang membolehkannya dalam kitab Hasyiyatul Jamal dan Imam Bulqini dalam Ghoyah Talkhisil Murad Hamisy Bughyatul Mustarsyidin (hlm. 112), namun musyawirin lebih memilih yang tidak boleh ihtiyathon (hati-hati).

Teks arab dari kitab Ghoyah Talkhisil Murad Hamisy Bughyatul Mustarsyidin adalah :

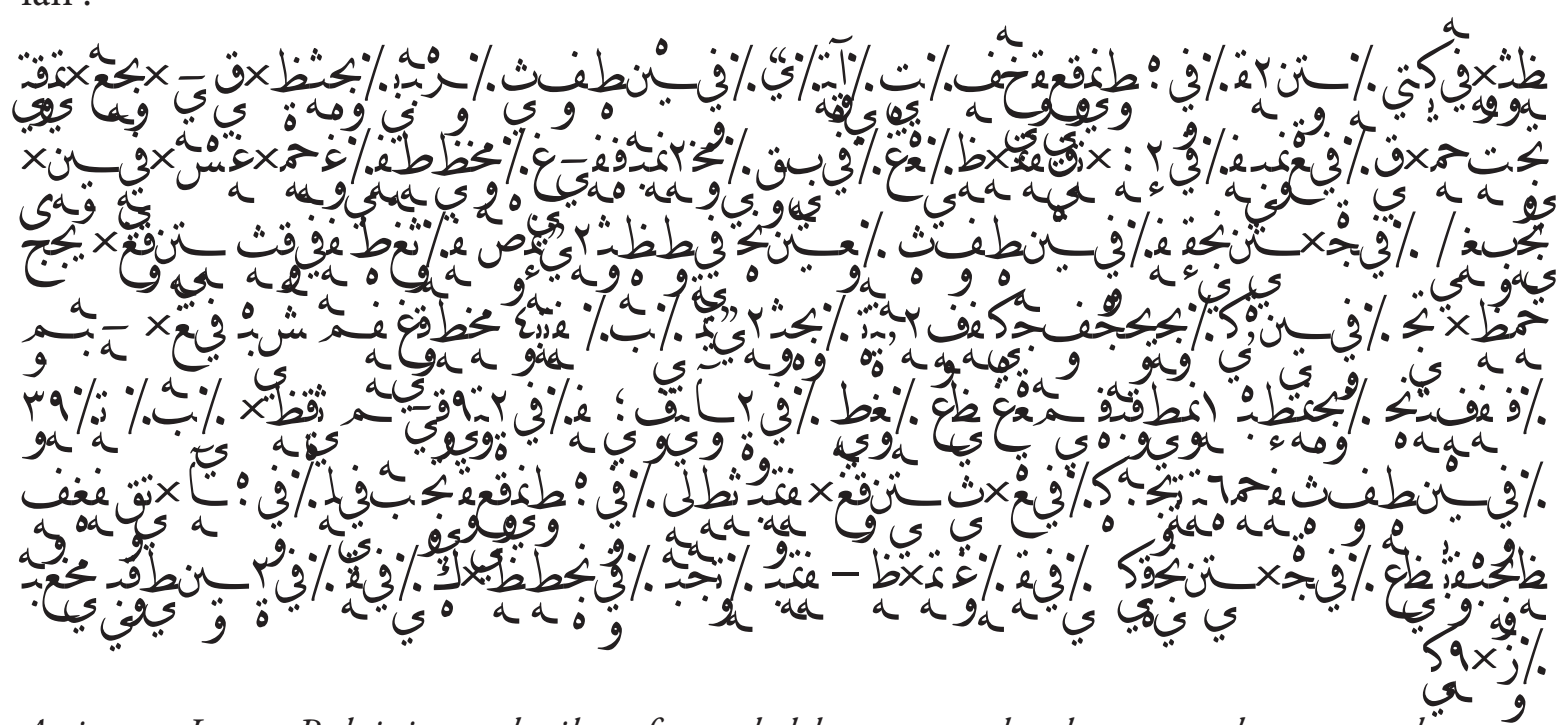

Artinya : Imam Bulqini memberikan fatwa bolehnya mengeluarkan uang baru yang bernama manaqir (bemata runcing) dalam zakat emas-perak dan dagang, ia berkata sesungguhnya ia sudah meyakininya, pendapat ini bisa diamalkan walaupun berbeda dengan madzhab Imam Syafi', uang lebih bermanfaat bagi orang-orang yang berhak menerima zakat dan lebih, dan didalamnya tidak ada penipuan seperti dalam perak yang ditipu. Orang yang berhak menerima zakat merasa sulit jika mendapatkan perak tipuan dan tidak menemukan ganti. Orang yang taqlid (mengikuti) dipersilabkan mengikutinya, karena Ia (imam BUlqini) termasuk abli takhrij (mengeluarkan pendapat terbaik) dan abli tarjih (mengunggulkan pendapat), apalagi jika uang laku dan banyak manusia yang menyenanginya. Dan (pendapat) Imam Bukhari menyamai pendapat Imam Bulqini. Ia 4 KH. MA. Sahal Mahfudh, Pesantren Mencari Makna, Pustaka Ciganjur, 1999, hlm. 89-90 
dihitung termasuk golongan madzhab Syafi'i. sampai pada ucapan-para ulama memberi petunjuk untuk mengikutinya ketika ada kebutuhan.

Kedua, dalam forum bahtsul masail pondok pesantren (FBMPP) se-Jombang di Rejoso Peterongan Jombang, ada kasus bolehkah perempuan menjadi Imam shalat, jawaban yang diambil tidak boleh. Yang menarik bukan jawabannya, tapi perdebatan sengit kedua belah pihak. Yang membolehkan berdasarkan hadits shohih, yang tidak memperbolehkan berdasarkan hadits dhoif. Hal ini berdasarkan hadits Nabi Muhammad yang berbunyi :

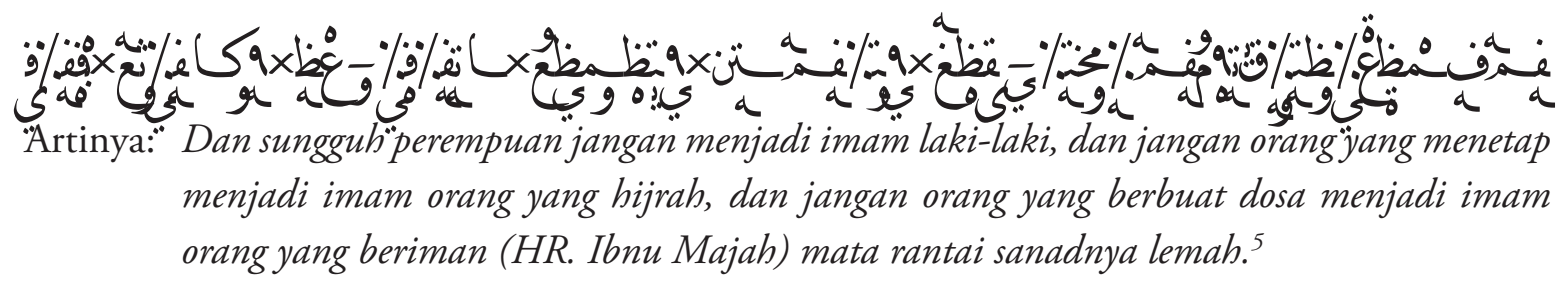

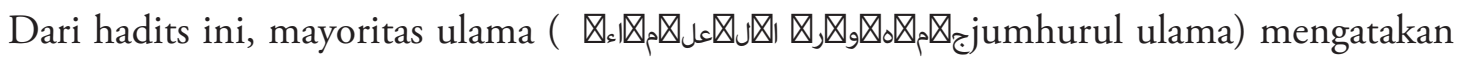
perempuan tidak sah menjadi imam bagi laki-laki. ${ }^{6}$

Sedangkan kubu yang memperbolehkannya menggunakan hadits sebagai berikut :

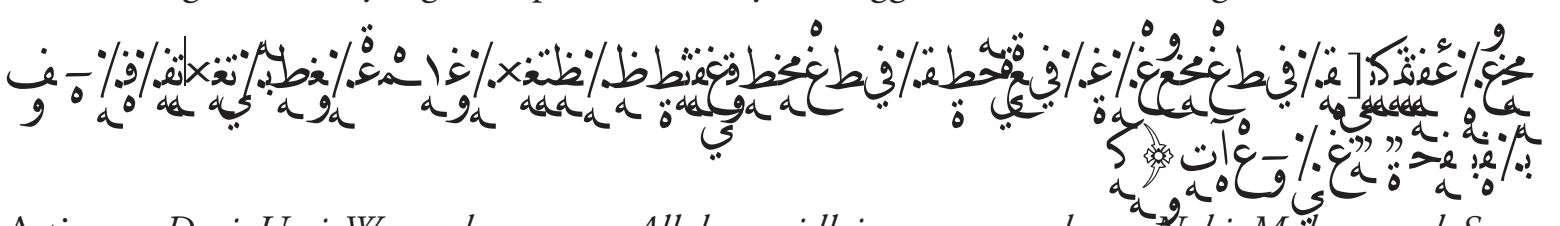

Artinya: Dari Umi Waraqoh, semoga Allah meridloinya, sesunguhnya Nabi Mühammad Saw.

Memerintahkannya supaya menjadi Imam bagi anggota kelurganya. Hadits ini statusnya shohih menurut Ibnu Khuzaimah

Sedangkan Ummi Waraqoh mempunyai budak laki-laki dan perempuan. ${ }^{7}$ Sebagian pengikut madzhab Syafi'i ada yang memperbolehkan perempuan menjadi Imam shalat khusus pada keluarga dan kerabat. Sebagian lagi membolehkan jika perempuan lebih fasih bacaan qur'annya dari pada laki-laki, namun perempuan harus berada dibelakang makmun laki-laki dan mereka harus mengikuti seluruh tindakan Imam perempuan dibelakangnya. Mayoritas ulama memilih kebolehan perempuan menjadi Imam secara global (

Dua contoh diatas bisa diambil pelajaran ke depan.

Pertama, kita harus mempelajari berbagai pemikiran, dan menghindari fanatisme, sehingga bisa menjadikan beragam pemikiran sebagai alternatif ketika menghadapi kondisi yang tidak mungkin ditolak. Ini yang kita sebut tarjih kontekstual, mengunggulkan hukum sesuai dengan kondisi sosial-budaya yang mengitari, tidak memaksakan, sepanjang masih ada yang

5 didalam hadits ini ada Abdullah bin Muhammad al-Adawi dari Ali bin Zaid bin Jad'an. Adawi dianggap Imam Waki' mengarang hadits (wadh'ul hadits), dan gurunya Ali bin Zaid lemah, baca dalam catatan kaki Muhammad Hamid al-Faki dalam kitab Bulughul Maram, hlm. 82, Pustaka Alawiyah Semarang

6 Hasan Sulaiman al-Nawari dan Alawi Abbas al-Maliki, Ibanah al-Ahkam Syarah Bulughul Maram, Darul Fikri, tt. hlm. 20

7 Ibid, hlm. 30-32

8 baca dalam al-Mabda', Juz 2, hlm. 72, juga dalam Subul al-Salam, Juz 2, hlm. 29 
memperbolehkan itu dipakai. Salah satu contoh bagus dalam hal ini adalah keterangan yang ada dalam kitab Tausyih dan Kifayah al-Akhyar, yaitu :

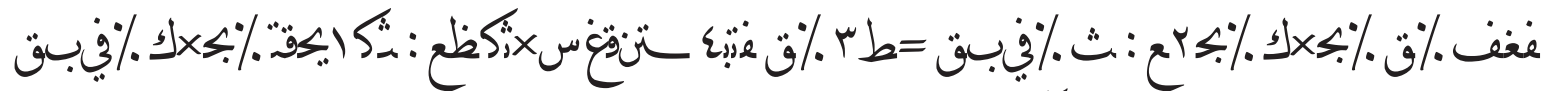

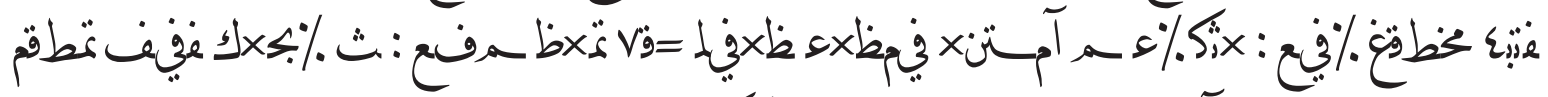

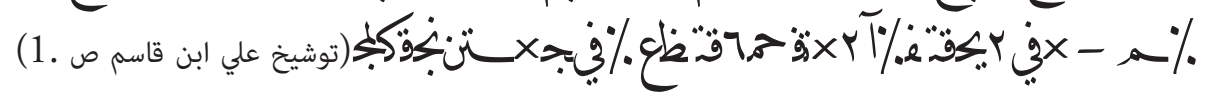

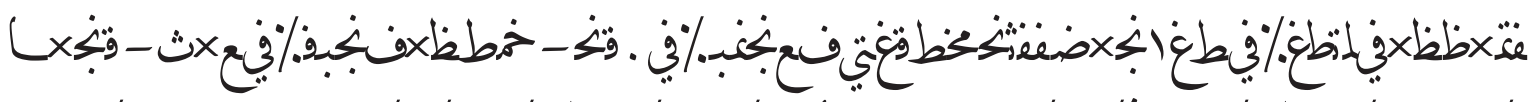
ع

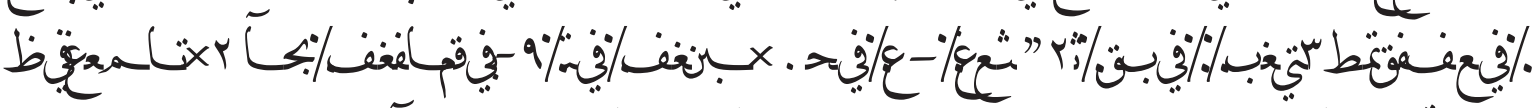

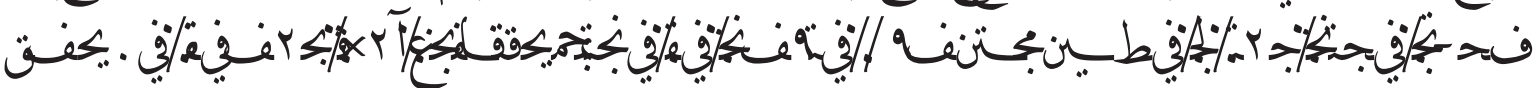
هبs

تمط س \%

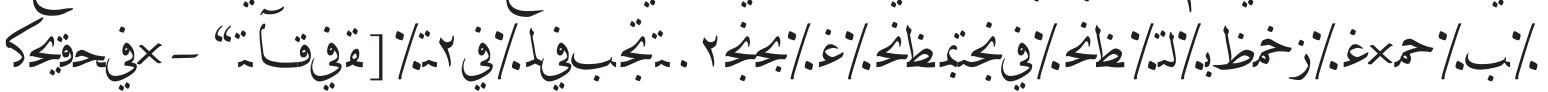

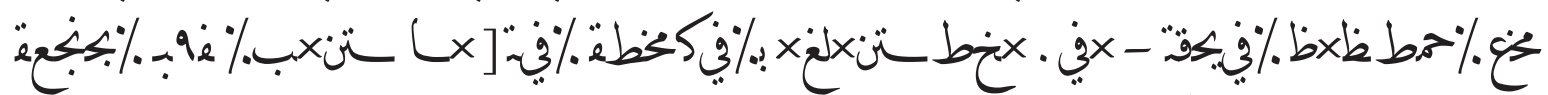

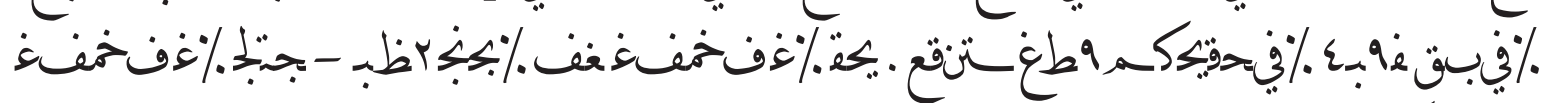

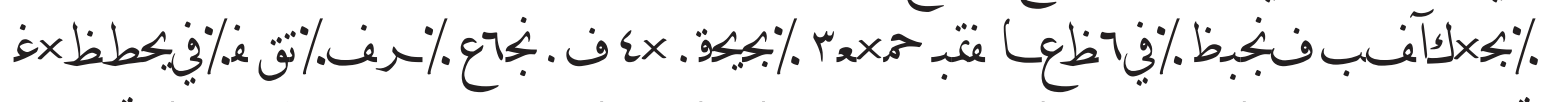

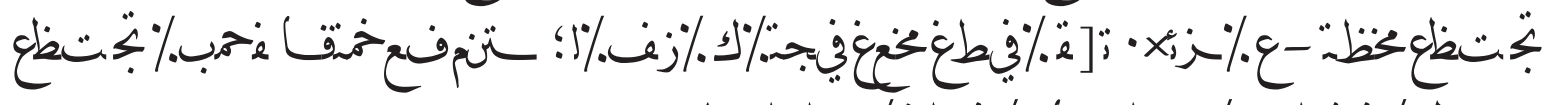

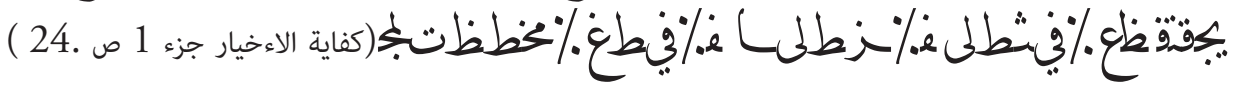

Kedua, kita harus memperkuat dan melengkapi pemahaman fiqh kita dengan al-Qur'an dan Hadits. Keputusan MUI mulai cabang sampai pusat sekarang ini sepanjang pengetahuan penulis tidak terikat sama sekali dengan madzhab, mereka langsung menggunakan al-Qur'anHadits, pendapat ulama hanya sebagai penguat. Oleh sebab itu, kita harus memulai kajian induktif, dari fiqh, ushul fiqh, qowa'id fiqh, hadits dan al-Qur'an. Pondok Lirboyo pada forum bahtsul masail Fathul Wahhab (level di atasnya fathul Mu’in) sudah melakukan ini. Proses kajian induktif ini sangat berguna dalam melatih proses istimbathul ahkam.

\section{Fiqh Maslahah}

Menurut Gus Dur dalam pengantar bukunya Masdar Farid Mas'udi (Risalah Zakat Pajak) mengatakan, sebaik apapun sebuah pemikiran dari sisi teoritik, jika tidak membawa kemanfaatan riil bagi masyarakat tidak banyak manfaatnya. Salah satu kelemahan fiqh adalah karakteristiknya 
yang legalis-stagnan-final. Legalis, artinya menetapkan hukum hanya dengan pertimbangan teks semata, tanpa mendalami makna intrinsic-substansialnya, atau maqoshit syar'iyyahnya (tujuan aplikasinya). Stagnan, artinya berjalan ditempat, tidak maju ke depan, orientasi ke belakang, tanpa memandang kemajuan ke depan. Final, artinya, menganggap semua konsep yang ada dalam kitab fiqh, baik kaitannya dengan ibadah mahdhoh atau mu'amalah, sebagai konsep yang baku, tidak berubah, permanen.

Karakter legalis-stagnan-final ini membawa fiqh pada simbolisme formalistik. Karakter formalistik semacam ini menurut Masdar Farid Mas'udi' tidak pernah menelusuri untuk apa suatu hukum ditetapkan, dan buat kepentingan siapa. Yang penting baginya adalah bahwa suatu pemikiran hukum, dalam kasus apapun, bisa dipertangung jawabkan secara formal pada bunyi teks (nash) tertentu. Tak soal, apakah hukum itu dalam kenyataan historisnya telah menyentuh kemaslahatan orang banyak atau hanya menyantuni kepentingan sekelompok orang saja. Atau bahkan, ketika pemikiran hukum itu sudah tidak berhubungan dengan kepentingan siapapun. Asal secara formal terdapat teks yang bisa dijadikan rujukan, maka suatu pemikiran hukum, dalam tradisi fiqh kita sampai sekarang, telah dianggap sah.

Untuk menghindari hal ini, mengetahui maqosid al-syari'ah adalah suatu keniscayaan.

Fiqh harus mampu menggapai kemaslahatan publik secara luas. Term maslahah ini menjadi krusial dalam fiqh. Bahkan ia menjadi salah satu syarat berijtihad. Menurut Imam Syathibi, ijtihad didasarkan pada dua sumber : Pertama, memahami tujuan syari'at, bahwa ia dibangun pada kemaslahatan Islam, yakni esensi konkrit, tidak melihat keinginan dan syahwat orang mukallaf, tapi dengan melihat persoalannya pada dzatnya, apakah membawa kemanfatan atau bayaya. Imam Syathibi berkata dalam masalah ini "ketika manusia telah sampai pada tingkat dimana ia memahami tujuan pembuat hukum (Syari') dalam setiap masalah dalam masalah-masalah syari'ah, pada setiap bab dalam semua babnya, maka dia telah berhasil sifat yang menjadi faktor sampainya pada kedudukan pengganti Nabi Shollahu Alaihi Wasallam dalam pengajaran dan fatwa dan menghukumi seperti yang diperlihatkan Allah SWT”. Sumber kedua yang disebutnya adalah mampu mengambil dan menetapkan hukum dengan penguasaan bahasa arab, hukum-hukum alquran dan sunnah, ijma', perbedaan pendapat diantara ahli fiqh, aspek-aspek qiyas. Semua ini adalah instrumen ijtihad. Syathibi berkata, "sumber pertamanya adalah dasar, adapun yang kedua adalah pembantu, karena memahami tujuan syari adalah pengetahuan yang digunakan untuk membangun ijtihad, pengetahuan-pengetahuan lain dari bahasa, hukum-hukum alquran dan lainnya adalah hukum praktis-operasional yang tidak menghasilkan keputusan hukum baru jika tidak dibangun pada kesempurnaan ilmu dari tujuan syari". Syathibi berkata "sumber yang kedua sebagai pelayan sumber pertama".${ }^{10}$ Menuju kesana, kita harus mengedepankan fiqh manhaji.

Fikih sosial merupakan manifestasi dari fikih maslahah karena implikasi riilnya pada dimensi

9 Baca dalam Menggugat Tradisi, Pergulatan Pemikiran Anak Muda NU, editor: Zuhairi Misrawi, KompasP3M, September 2004, hlm. 59

10 Yasin Asymuni, Ijtihad wa al-Taqlid, Hidayah al-Thullab Petuk Kediri, 3-10. 
aksiologis, yaitu pemberdayaan ekonomi masyarakat menengah ke bawah dengan pendekatan kebutuhan pokok (basic need approach) yang dikelola secara akuntabel dengan manajemen partisipatoris.

\section{Fiqh Manhaji}

Fiqh manhaji berarti fiqh yang mengikuti metodologi pemikiran ulama, bukan produk pemikirannya. Kalau mengikuti metodologi, produknya bisa sama, bisa berbeda. Berpikir metodologis berarti menghindari tekstualitas ansich tanpa ada kajian filosofis-metodologisnya.

Mengambil teks ansich tanpa mengetahui tujuan hukum tersebut bisa mengakibatkan kesesatan dalam agama. Seperti ditegaskan Imam Al-Qarafi dalam kitabnya Al-Furu':

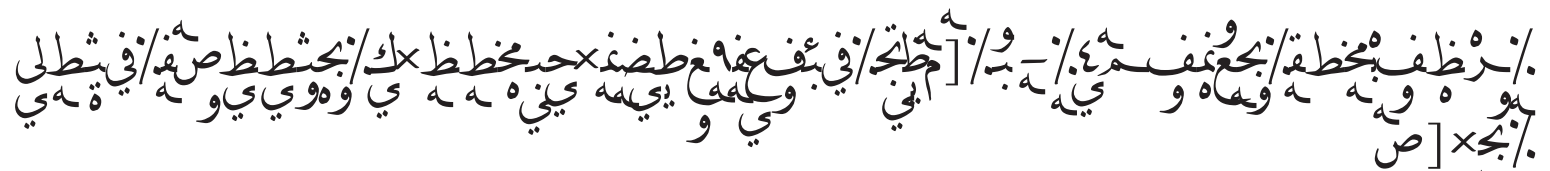

Artinya: Kaku dalam mengambil apa-apa yang dinukil selamanya adalah sesat dan (tandâs bodón dengan tujuan ulama-ulama'nya umat Islam dan yang orang-orang terdahulu yang sudah lalu. ${ }^{11}$

Dalam kitab Majmu'atu Sab’ati Kutubin Mufidah, karya Syekh Sayyid Alawi bin Ahmad al-Saqqaf, hlm. 70 dijelaskan alasan Syafiiiyah (pengikut madzhab Imam Syafi'i) memilih bukan pendapat Imam madzhabnya :

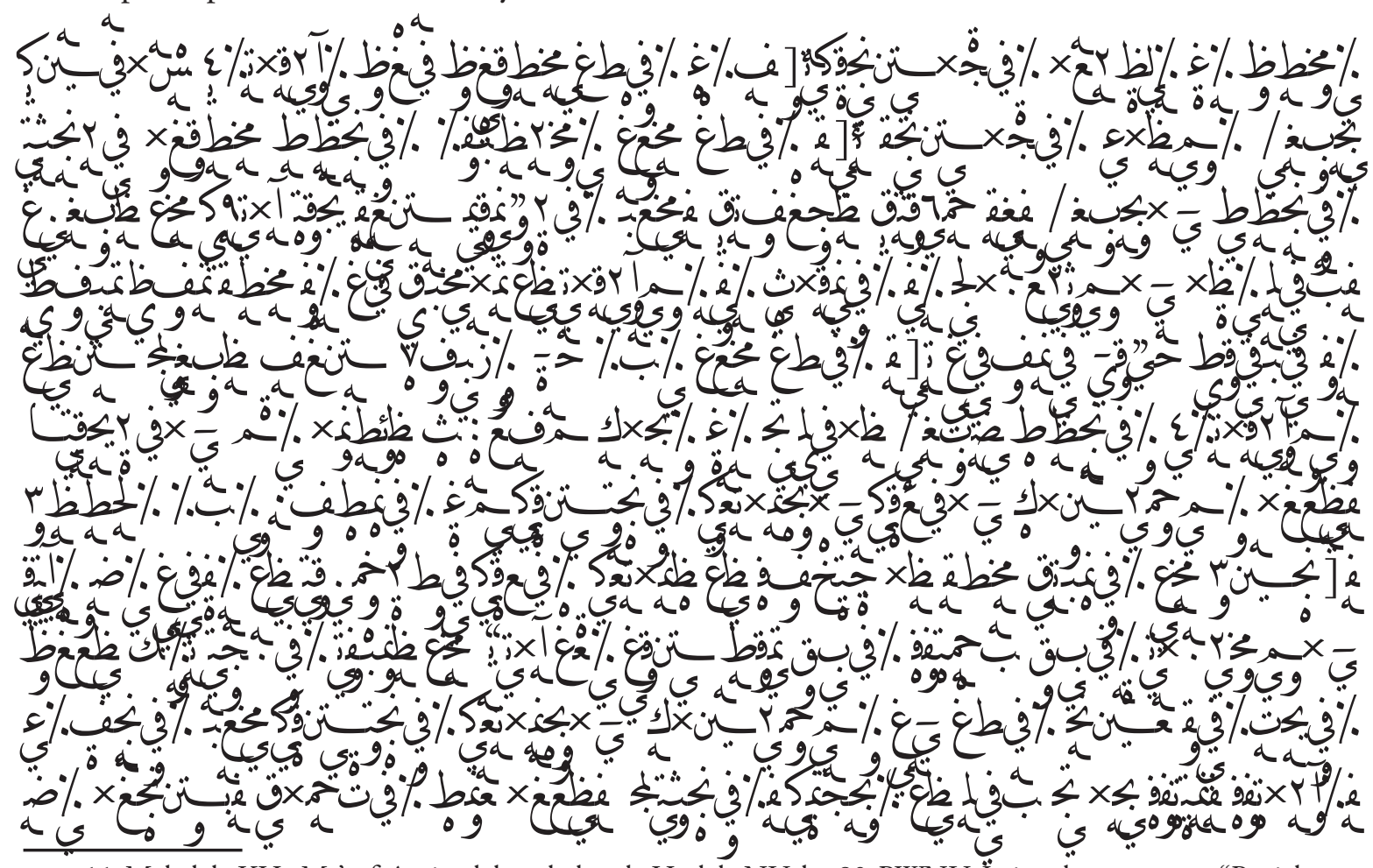

11 Makalah KH. Måruf Amin dalam halaqoh Harlah NU ke-80 PWNU Jatim dengan tema "Penjabaran Sistem Pengambilan Keputusan Hukum Dalam Bahtsul Masail di Lingkungan Nahdlatul Ulama sebagai hasil keputusan Munas Alim Ulama di Lampung", di Pondok Pesantren Tebuireng, Jatim, tanggal 13 September 2003 


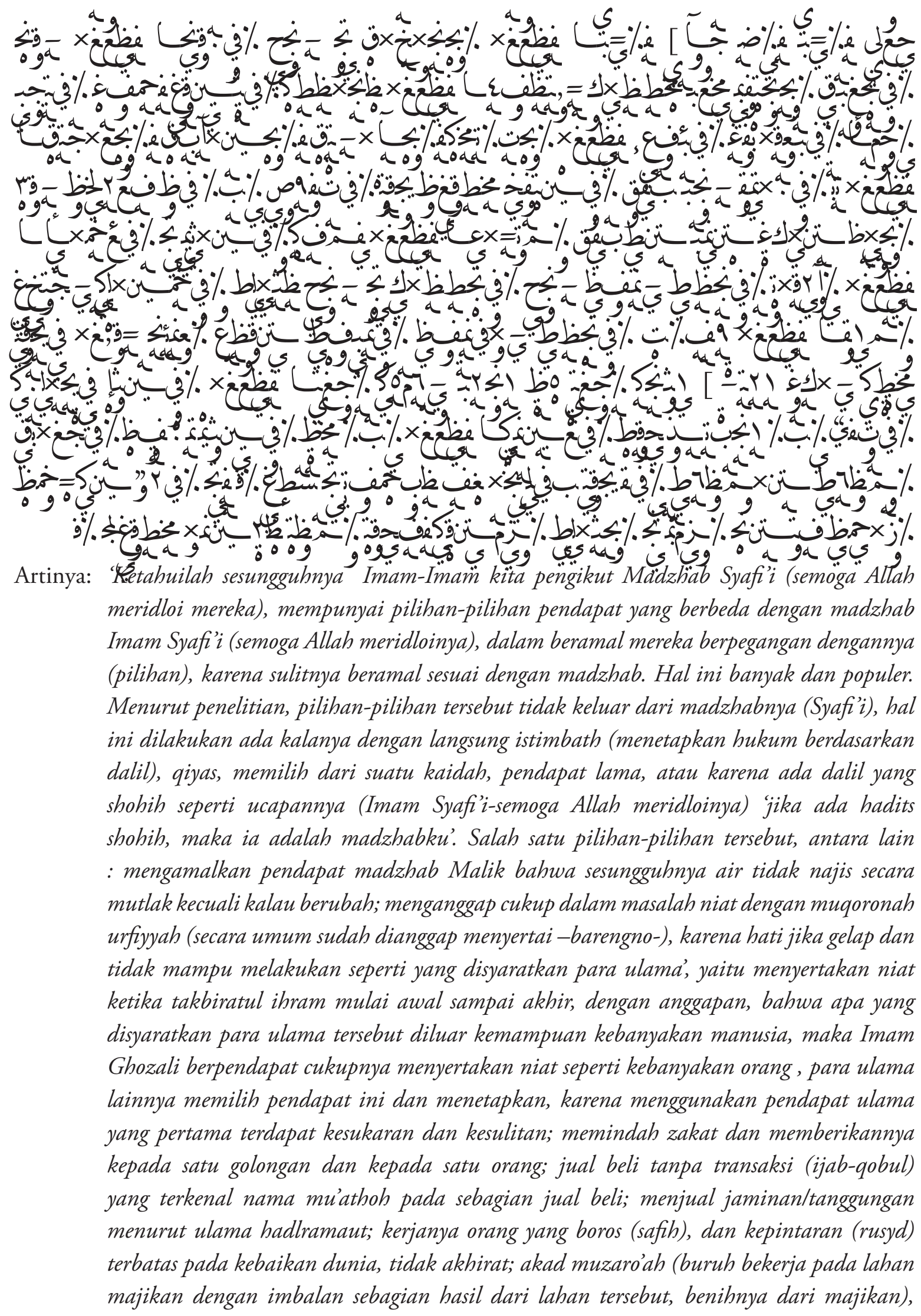


mukhobarah (buruh bekerja pada lahan majikan dengan imbalan sebagian hasil dari lahan tersebut, benihnya dari buruh), mufakhodzah (paha laki-laki menempel pada paha laki-laki-tapi tidak homoseks), dan munasyarah (menyiarkan/ menyebarluaskan sesuatu); mengembalikan sisa setelah orang yang mendapatkan bagian selain suami-istri, ketika bait al-mal (pusat anggaran negara) tidak mengurusi, jika tidak ada maka diberikan kepada sanak kerabat; orang fasiq menjadi wali nikah; memilih mengamalkan pendapat sebagian ulama dalam sebagian masalah kafaah (kesesuaian, keselarasan, dan kepantasan) dengan syaratnya yang akan datang; bolehnya mengamalkan qoul qodim (pendapat Imam Syafi'i ketika di Baghdad Iraq) dalam masalah perempuan yang darah haidlnya terputus tanpa ada penyakit, dengan gambaran ia menunggu selama sembilan bulan kemudian iddah (masa menunggu untuk memastikan kekosongan rahim) selama tiga bulan; bubarnya perkawinan sebab hilangnya suami jika sulit menghasilkan nafkah; jika kefasikan sudah menjadi pemandangan umum maka diterima persaksian orang yang lebih sepadan, lalu yang sepadan dan lain-lainnya seperti yang disebutkan pada tempatnya, dalam kitab Tuhfah disebutkan keputusan hakim menghilangkan perbedaan dalam masalah-masalah yang penuh perbedaan dan jadilah masalah tersebut disepakati bersama.

Dalam kitab Nihayah al-Zain hlm. 181-182, Imam Nawawi al-Bantani juga memberikan contoh :

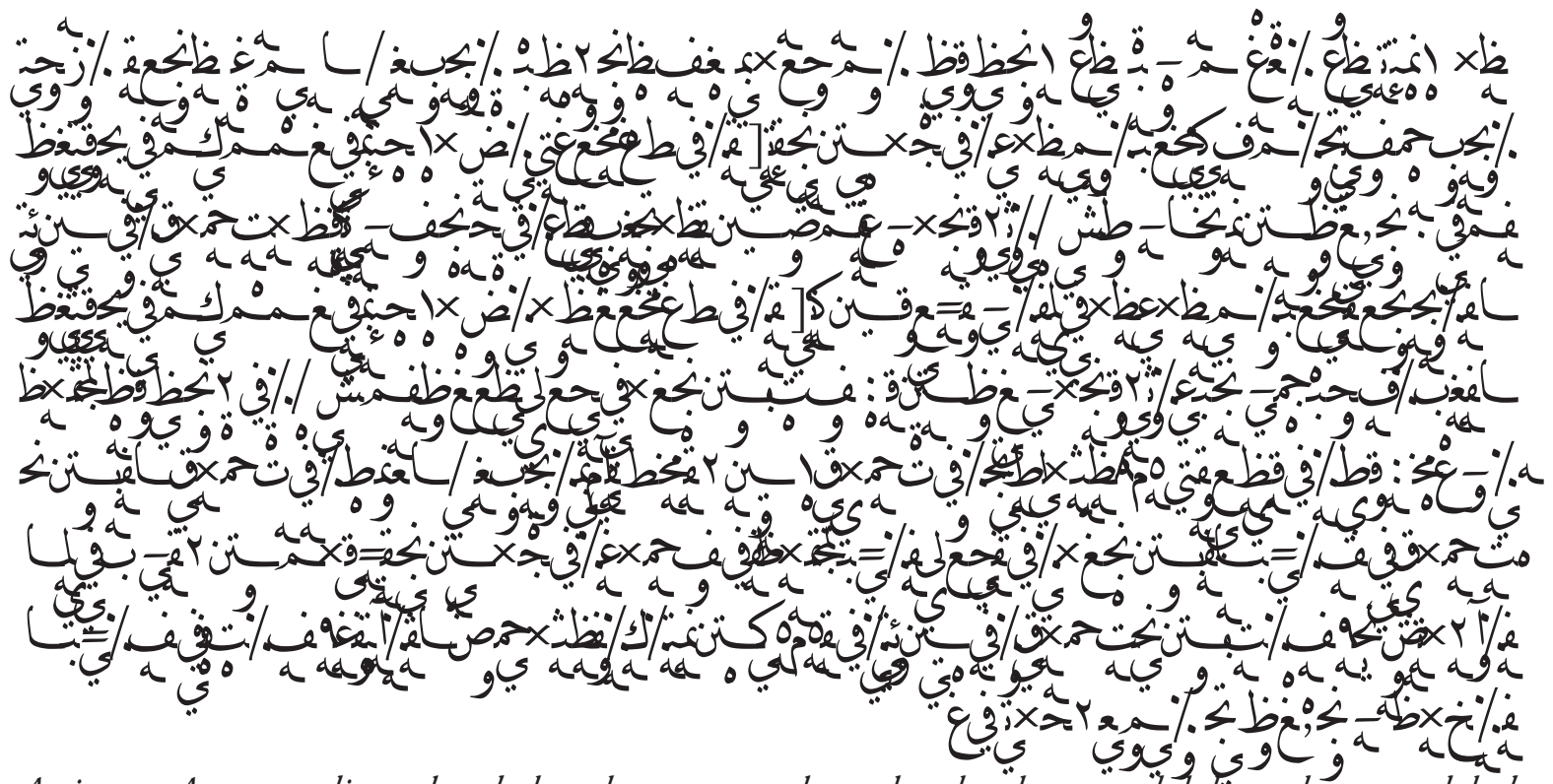

Artinya: Apayang ditetapkan bahwa harus meratakan seluruh golongan ädalatis pendapat madzhab yang bisa dibuat pegangan (mu'tamad). Karena pengertian meringkas yang disebut dalam ayat menurut Imam Syafi'i ra. adalah digunakan bagi mereka semua, bukan yang lain, dan bukan pada sebagian saja, tapi wajib meratakannya, dalam masalah ini tidak samar lagi membawa kesulitan, apalagi dalam zakat fithri. Pengertiannya menurut Imam Malik dan Abu Hanifah ra. digunakan untuk mereka semua, bukan yang lain. Pengertian ini membenarkan tidak harus rata, boleh memberikan kepada satu golongan dari mereka, dan 
tidak wajib rata. Imam Ibnu 'Ujail al-Yamani berkata : tiga masalah dalam zakat yang dibuat fatwa berbeda dengan madzhab, memindah zakat, memberikan zakat kepada satu orang, dan memberikan zakat kepada satu golongan. Ia berkata, seandainya Imam Syafi'i masih hidup, niscaya ia akan memberi fatwa dengan hal ini. Golongan ulama Syafi'iyyah memilih bolehnya memberikan zakat fithri kepada tiga orang fakir atau miskin, dan yang lain membolehkan pada satu orang, sebagian ulama memanjangkan (pembahasan) untuk menolong padanya (masalah ini).

Ini menunjukkan bahwa bermadzhab tidak harus absolut dan fanatik dengan memandang realitas sebagai obyek yang dipaksa mengikutinya. Disamping itu, memahami tujuan aplikasi hukum juga penting. Para ulama memilih pendapat yang berbeda dengan Imam Syafi'i karena pada zamannya pendapat Imam Syafi'i terasa sulit diterapkan melihat perkembangan dan perubahan sosial yang terjadi. Apalagi di era sekarang yang populer dengan era 'globalisasi dan 'modernisasi'. Perubahan dahsyat terjadi tanpa henti mengharuskan insan fiqh meresponnya secara akomodatif dan fleksibel, bukan dengan paradigma konfrontatif, antagonis, dan suka mem-black list hal-hal baru. Memilih pendapat lain yang berbeda bukan suatu kemungkaran, justru indicator kecerdasan para ulama masa lalu yang kritis-konstruktif agar madzhab Imam Syafi'i tidak ditinggalkan pengikutnya.

Hal ini diperkuat statement Imam Suyuthi yang disampaikan Imam Kurdi dalam kitab I'anah al-Tholibin, karya Syekh Abu Bakar Syatha, Juz 2, hlm. 197, yaitu :

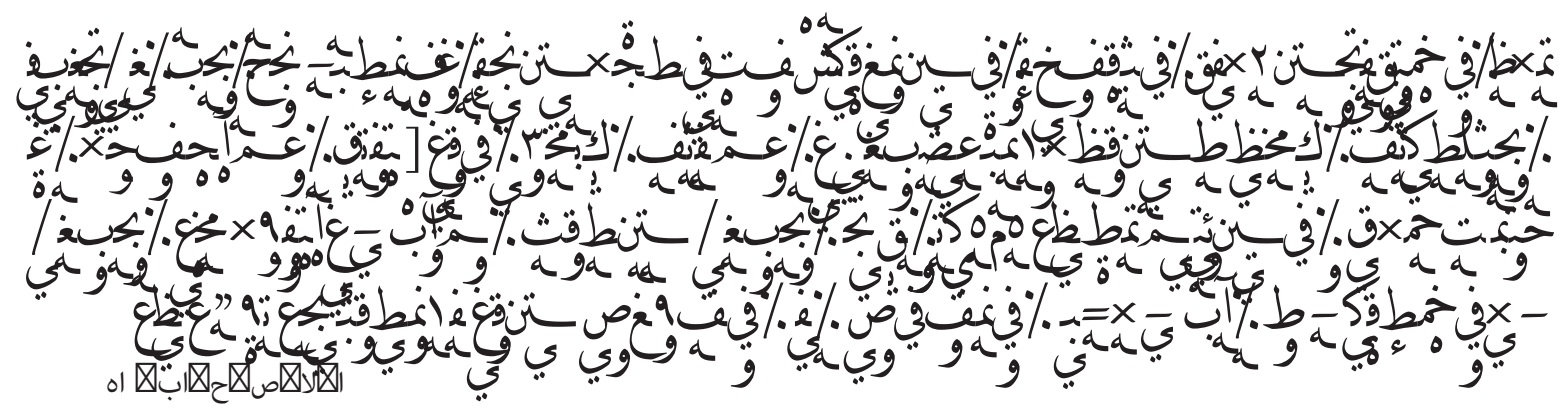

Artinya: Imam Kurdi berkata, dalam fatwa-fatwa Imam Suyuthi dalam masalah fiqh, boleh bagi orang yang mengikuti madzhab Syafii mengikuti sebagian beberapa madzhab dalam masalah ini, baik ia sudah mengamalkan dalam masalah yang telah lewat dengan madzhabnya atau tidak, dan baik didorong oleh kondisi darurat apa tidak, lebih-lebih bahwa memberikan zakat fithrah kepada kurang dari tiga adalah pendapat dalam madzhab, maka mengambil pendapat ini tidak keluar dari madzhab secara keseluruhan, tapi justru mengambil salah satu dari dua pendapat atau dua cara (wajh) didalamnya dan mengikuti pada ulama yang telah mengunggulkannya dari beberapa murid Imam Syafi'i.

Fikih sosial Kiai Sahal adalah fikih manhaji, karena menggunakan metodologi yang jelas.

Metodologi fikih sosial Kiai Sahal adalah:

Kontekstualisasi kitab kuning melalui pengembangan contoh-contoh aplikasi kaidah- 
kaidah Ushul al-Fiqh maupun Qawa'id al-Fiqhiyah.

Pengembangan teori masalik al-'illah agar fiqh yang dihasilkan sesuai dengan maslahat alammah. ${ }^{12}$

Tipologi pemikiran KH. MA. Sahal Mahfudh yang maju dan progresif ini menurut Mujamil Qomar masuk tipologi elektik, yaitu suatu pemikiran yang berusaha memilih semua yang dianggap terbaik tidak peduli dari aliran manapun, filsafat manapun dan teori manapun, asal lebih baik dri pada yang lain, itulah yang dipilih. Dalam diskursus filsafat, salah satu pengertian elektisme adalah 'memilih gagasan (konsep, keyakinan, doktrin) dari bermacam system pikiran dalam proses menyusun system kita sendiri'. Dalam bahasan ini, pemikiran yang berpola eklektik bisa berwujud menyatakan pandangan yang kurang lazim diukur dari kultur orang yang menyatakan pendapat itu sendiri. ${ }^{13}$

\section{E. Menggagas Fiqhul Hadlori}

Fiqh sosial KH. MA. Sahal Mahfudh adalah embrio dari lahirnya fiqh hadlori (fiqh peradaban). Fiqh yang mampu melahirkan peradaban baru yang progresif, modern, dan produktif dalam melahirkan karya intelektual dan sosial. Dalam konteks ini, generasi muda harus kreatif meneruskan dan mengembangkan warisan pemikiran 'genuine' dari pemikiran KH. MA. Sahal Mahfudh. Fiqh sosial KH. MA. Sahal Mahfudh ini bisa menjadi mediator antara dua kecendrungan, liberalisasi dan fundamentalisasi. Fiqh tetap berpijak pada teks, namun selalu melihat realitas secara transformatif.

Wacana keislaman saat ini berjalan secara sangat massif. Ada banyak payung terminologis, liberal, emansipatoris, moderat, post tradisionalisme, dan lain-lain. Masing-masing saling mengklaim yang terbaik.

Bagi kelompok fundamentalis, seruan kembali dan berpegang teguh kepada tradisi dan orisinalitas merupakan bagian dari mekanisme kebangkitan untuk maju karena dengan tradisi itulah masa kini dan masa lalu yang agak dekat dapat dikritik. Bagi mereka, Islam yang dicontohkan oleh salaf al-shalih merupakan bentuk keberagamaan yang paling benar dan ideal. Karena itu, keunikan ekspresi keberislaman masyarakat Indonesia dicerca sebagai "kejahiliyahan modern" yang jauh dari Islam yang benar, otentik. asli. Otentisitas (ashalah) Islam hilang ketika ia telah dicampuri oleh unsur luar. Islam Indonesia kehilangan nilai keasliannya semenjak ia mengakomodasi dan berakulturasi dengan budaya dan tuntutan lokal. Masuknya warna budaya lokal inilah yang dipandang melahirkan bid'ah atau khurafat. (Tashwirul Afkar, edisi No. 14 Tahun 2003, hlm. 11).

Bagi kelompok liberal-rasionalis, menggunakan jalur shout-cut dengan mendekonstruksi semua elemen ajaran suci adalah suatu keniscayaan. Kelompok ini melakukan liberalisasi pemikiran tanpa sebentuk distinction apapun. Satunya-satunya acuan yang mesti dipegangi,

12 KH. Sahal Mahfudh, Fiqh Sosial, Upaya Pengembangan Mazhab Qouli dan Manhaji, Teks Pidato Penganugrahan Gelar Doktor Honoris Causa di UIN Syarif Hidayatullah Jakarta, 18 Juni 2003

13 ibid, hlm. 251 
menurut kelompok ini adalah keadilan menyeluruh sesuai semangat disyari'atkannya Islam. (Abu Yazid, 2004). Kelompok kedua ini terlalu overacting dalam mengapresiasi Barat dan globalisasi tanpa reserve, mereka terlalu cepat melakukan reformulasi paradigma klasik menjadi paradigma liberal. Bukti faktual kelompok ini adalah rancangan rumusan "counter legal draft" yang mengharamkan poligami, hak warist setara laki-perempuan, dan persamaan HAM. Kelompok ini mempunyai beberapa metodologi. Pertama, mengubah paradigma dari teosentrisme ke antroposentrisme. Kedua, bergerak dari eisegese ke exegese. Dengan exegese, para penafsir berusaha semaksimal mungkin untuk menempatkan teks agama sebagai "obyek" dalam suatu dialektika yang seimbang. Ketiga, memfikihkan syari' at. Syari'at harus diposisikan sebagai jalan (wasilah) yang berguna bagi tercapainya prinsip-prinsip Islam (ghayat) berupa keadilan, persamaan, kemaslahatan, penegakan HAM. Keempat, kemaslahatan sebagai rujukan dari seluruh kerja penafsiran. Kelima, mengubah gaya berpikir deduktif ke induktif (istiqra'iy). (Abdul Moqsith Ghozali, 2005). Paradigma ini didukung oleh Nash Hamid Abu Zayd, menurutnya, ada lima pola wacana keagamaan dewasa ini yang tertutup. Pertama, menyatukan antara agama dan pemikiran. Jarak pemisah antara agama dan hasil pemahaman agama (ijtihad) terhadap agama tidak dipisahkan secara jelas. Sehingga ketika ada pemahaman lain yang bertentangan dengan pemahamannya dianggap melanggar agama. Kedua, teologisasi fenomena sosial dan alam.

Dalam wacana ini, hukum kausalitas (sebab-musabab) tidak dilihat sebagai faktor utama. Semua kejadian baik yang pada dasarnya realitas sejarah dan sosial dikembalikan kepada Allah. Akhirnya pemahaman ini mendorong manusia untuk malas, tidak mempunyai etos kerja dan lebih bersifat fatalis. Manusia tidak mempunyai kebebasan untuk berkemauan (free will), apalagi bertindak. Ketiga, interdependensi (ketergantungan) terhadap "salaf" dan "tradisi" (turast). Kelompok ini memandang masa lalu adalah segala-galanya. Hasil karya ulama terdahulu sudah melebihi dari cukup dan tugas sekarang sekadar mempraktekkannya. Perbedaan pendapat tidak dihargai jika bertentangan dengan tradisi dan pendapat ulama salaf. Dalam pandangan mereka, agama adalah tradisi Kaum Salaf dan jika bertentangan, dianggap menyimpang dari agama. Keempat, fanatisme pendapat dan menolak dialog. Setelah kelompok ini berlindung di balik tradisi (turast), mereka memiliki otoritas tersendiri untuk menafsirkan tradisi-tradisi ini. Otoritas ini hanya dimiliki oleh kelompok mereka, sedangkan kelompok lain tidak memiliki kebebasan untuk menafsirkan. Kelima, mengingkari dimensi historis (sejarah). Pola berpikir ini sebagai akibat dari pola-pola diatas. Hukum perubahan dan pergantian dipahami dari sudut teologi dari pada proses sejarah dan sosial. Tidak jarang, konsep-konsep yang pada mulanya tidak ada dalam ajaran Islam diyakini sebagai ajaran agama karena memiliki sejarah dan terjadi di komunitas Islam. Seperti konsep "Negara Islam" (al-Khilafah al-Islamiyah) yang dimulai dari Dinasti Umawiyah di Damakus (Syria) hingga Dinasti Utsmaniyah di Istanbul (Turki) (M. Guntur Romli, 2001).

Kelompok ini memang sangat pro-Barat, disharmoni dengan kalangan tradisional (walaupun mereka lahir dari kelompok ini), dan terlalu mudah mencampakkan kekayaan 
tradisi. Barometer validitas dan autentisitas keragaman pemikiran ini masih dalam taran teoritik-konseptual, tidak pada fungsi sosial progresifnya. Sedangkan sebaik apapun sebuah ide atau pemikiran, kalau tidak mampu membawa manfaat yang lebih baik kepada masyarakat tidak begitu ada gunanya (Abdurrahman Wahid, 1991). Pada aras ini kita harus bisa keluar dari dua aliran yang kontraproduktif bagi terciptanya bangunan peradaban yang holistic dan integral. Perpaduan al-asholah (tradisi) dan al-hadasah (modernitas) adalah kunci menuju kebangkitan. Fiqh harus mampu menjadi entry point kebangkitan intelektual dan penelitian menuju terciptanya bangunan peradaban yang progresif.

Dalam konteks tantangan pemikiran inilah, fiqh sosial Kiai Sahal lahir untuk menjawab secara tuntas problem integrasi otentisitas dan modernitas yang sering kontradiktif dan antagonistik. Selamat jalan begawan fiqh sosial, santri-santrimu akan senantiasa mengkaji pemikiranmu demi masa depan bangsa yang lebih baik. 